\title{
ENVIRONMENTS OF AESTHETIC DECAY
}

\author{
Sotes on a visual \\ ethnographic approach
}

\section{BY PANOS KOMPATSIARIS}

Dhotographic images exist as material objects that 1 travel, mediate affect, change hands, hard drives and online hosts, are used as forensic evidence, objects of symbolic exchange, generators of meaning. I am concerned here with the ways in which ethnographic research can engender questions of meaning while delving into the familiarities and unfamiliarities that riddle visual representations. More specifically, with how respective images that bear some formal and contextual resemblance could be used as a starting point for working with an ethnographic project. I do not intend to address the ways that the images themselves have been created - availability of technical equipment, means of transportation, the economic and social background of the producer and so on (although this would definitely tell us a lot about the particular contexts in which they appear). Rather, I intend to map a possible ethnographic reading that can emerge from the formal and contextual encounters between the two images presented in the text. On what grounds can an 'ethnographic account' start from these particular visual objects, 'follow' them and proceed in an investigation of their workings? 

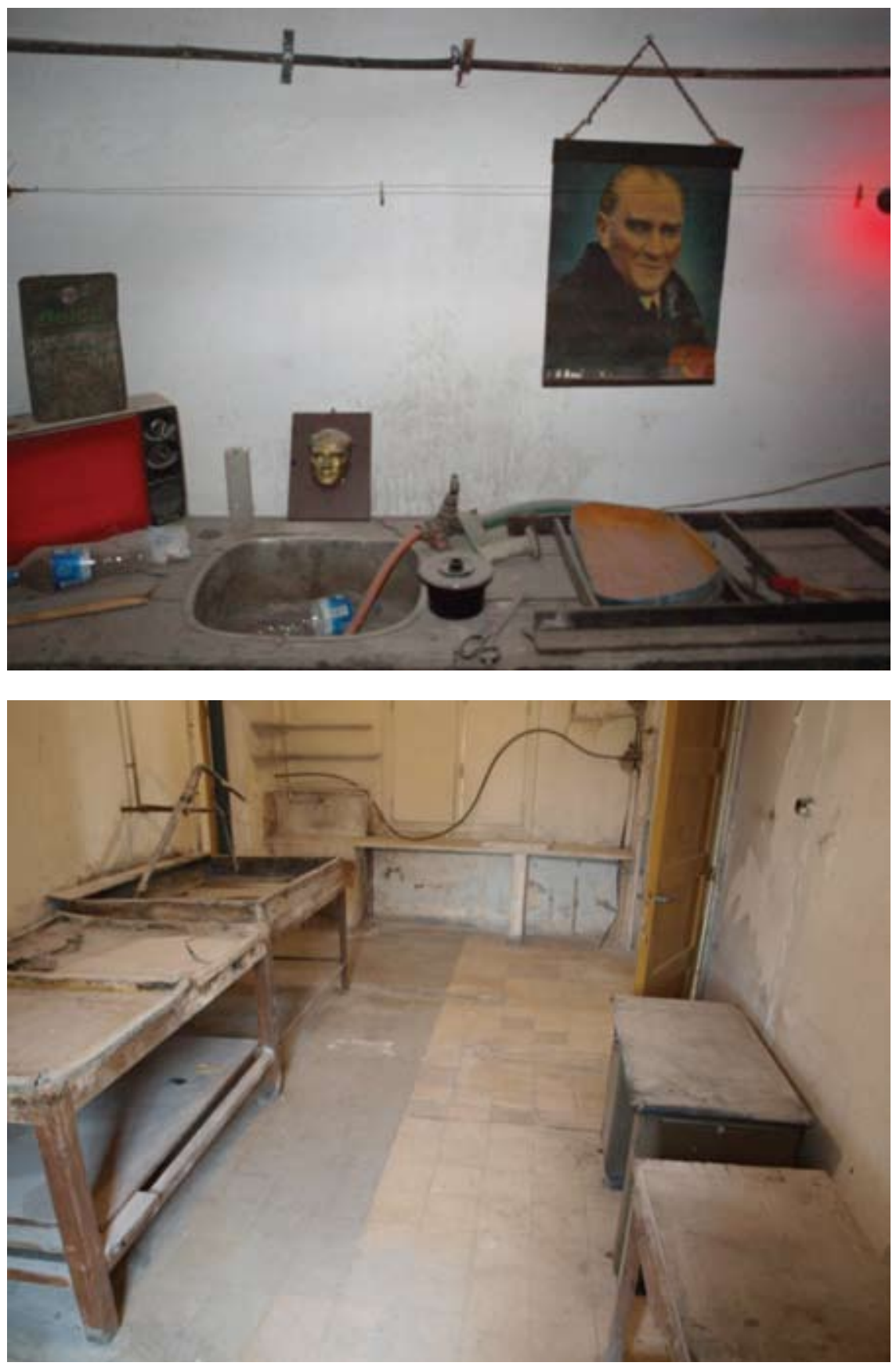

Photos (from top to bottom):

54th Venice Biennale, 2011; 3rd Athens Biennale, 2011

All photos by Panos Kompatsiaris

Both images have been taken by me in two different contemporary art biennials - the Venice Biennale and the Athens Biennale. The Venice Biennale is and has been one of the most established and well-funded institutions for showcasing contemporary art; it takes place in one of the most touristic cities in the world. The Athens Biennale, on the other hand, is an emerging and still poorly funded institution, that takes place in a city in crisis. The first image represents an artwork that appeared in the 54th Venice Biennale; the second one is an image of a random, but very characteristic part of the venue where the 3rd Athens Biennale was held. 
Let us briefly look at the images. We know that they are both taken at art biennales, that is to say, in sites where contemporary art is commonly showcased. They both show 'environments' that intend to acquire their meaning within a framed aesthetic regime of art-display. They bear, then, a contextual resemblance. If we look at their formal characteristics more closely, we will notice that a sense of ruin, destruction, squalor, abdication, dirt, dust, abandonment and discomfort runs through them. They, therefore, both seem to share a common aesthetic, a formal resemblance of decay.

A process of defamiliarizing these commonalities may begin by posing a random question, say the question of 'authorship' vis-à-vis these two staged 'environments'. This question is posed not from some methodological necessity, but from the standpoint of the contingent character of methodological processes, of any performed method of analysis.

If we proceed in our research by asking who is the 'author' of these 'environments', we may initially find out that the first picture depicts an 'environment' made by Mike Nelson, artist representing Great Britain in the Venice Biennale 2011. Nelson has transformed the British pavilion into an uncanny maze of dark corridors and dusty chambers, where hidden memories and traces could possibly manifest themselves. This was a creative process that lasted for three months, and where the 'creative gesture' is univocally attributed to the artist (as demonstrated by the general use of his name alongside the title of the work).

Later, we may also discover, that the second picture depicts not a carefully 'made' environment but an environment which has gradually 'decomposed' due to a 'socio-natural' process - the abandonment of a building and its gradual decay. Within the long-time sealed off building of central Athens Diplareios School, where the low-budget 3rd Athens Biennale was held, this environment comes to be with little or no 'creative' human intervention. In the case of Venice, authorship is unquestionably attributed to the artist, while in the case of Athens, authorship is attributed to the curators, who 'chose' to display art in the particular venue. The qualities of practice appear different: a physical creation of a temporary space to be demolished after the exhibition, and an appropriation of an already existing space in order to experience and possibly revitalize it after an ephemeral art event

After this brief encounter with the question of authorship, an art theorist could pose questions such as: What do these differences and similarities have to say about the sites where art is displayed? What do questions of aesthetic decay, cultural context, and economic viability have to say about the cities of Athens and Venice, their art audiences, their social composition, their 'global' character? Why does an artist choose to create ruins for aesthetic display? On the other hand, why does a curator choose to appropriate and aestheticize pre-existing ruin? The art theorist would then proceed in examining these questions through an experiential lens, attached to particular social and theoretical readings. 
In what ways can ethnographic research generate storylines, different from that of the art theorist? The ethnographer follows the images. She or he physically visits the cities and looks for arbitrary connections between them, examines the two different exhibitions. Who participated, how did the selection process proceed and why? How were these two sites produced? Why ruins, why destruction? The ethnographer then asks the organizers, the artists, the curators. Why all this decadence? What meaning do they put in the process of aestheticizing ruins? In what degree was this 'choice' dictated from material constraints? What does this have to say about agency, intellectual property and authorship in relation to the particular socio-economic contexts? What does it mean to turn a decayed environment into an object of aesthetic appreciation? In what other art venues has 'decay' been consciously or unconsciously put on display? The ethnographer visits them and observes them. What cultural codes need to be performed in order for them to plead for aesthetic appreciation? She or he then goes on to physically spend time in other squalid environments, say old abandoned buildings. In what ways is this experience different from experiencing ruins in an art exhibition? A first research question then can vaguely start to emerge: Under what conditions do decayed 'environments' enter the realm of art and what social processes determine their performance in relation to aesthetic appreciation?

The sites explored and studied will necessarily be multiple: decayed environments, art exhibitions, cityscapes. The ethnographer will then follow the abstract connections, concepts, threads and flows of such processes. In this sense, the "visual' can be the starting point of an ethnographic project, rather than its mere illustrative material or final outcome. (상 